CESIS Electronic Working Paper Series

Paper No. 328

\title{
Media clusters and metropolitan knowledge economy
}

\author{
Charlie Karlsson \\ Philippe Rouchy
}

October, 2013 


\title{
Media clusters and metropolitan knowledge economy
}

\author{
Charlie Karlsson ${ }^{1}$ and Philippe Rouchy ${ }^{2}$
}

\begin{abstract}
Large media clusters have emerged in a limited number of large cities, characterizing the geographical concentration of the global media industry. This paper starts by exploring the effect of the rapid advancement of Information and Communication Technologies (ICT) had on the media economy. It concludes that the role of the "weightless economy" on media cluster has enhanced its production and distribution functions. We review the specificities of media cluster that ties agglomeration to creative, diversified attributes of production and distribution. The implication is that media firms hold strong tendencies to cluster in urban regions since they make full usage of its resources, namely its export capabilities and import transformation strength. Finally, we invite researchers to consider Jacobs' metropolitan and global reciprocating system of city growth as a valid unit for analysing media clusters. The question leads envisaging if media clusters' strong metropolitan base allows them to grow further through globalised circuits. The paper concludes that large, media clusters drive on intellectually dense network of information, which can only be cultivated through large agglomerations existing capabilities. Consequently, the research question focuses upon the economic role of knowledge in media creation and export replacement. We emphasize the strength of Jacob's model of media cluster for understanding its mechanism of value creation and endogenous system of globalisation.
\end{abstract}

Keywords: Clustering, media industry, agglomeration, weightless economy, creative industry, globalization, regional development.

JEL Classification codes: R11，L82

\footnotetext{
${ }^{1}$ Jönköping International Business School, P.O. Box 1026, SE-551 11 Jönköping, Sweden charlie.karlsson@jibs.hj.se

${ }^{2}$ Department of Management, Bleking Institute of Technology, Valhallavägen, SE-371 41 Karlskrona, Sweden, philippe.rouchy@bth.se
} 


\section{I- Introduction to media cluster and knowledge dynamics}

Since roughly the mid-90s, thanks to the advent of new information technology, the interrelationship between ICT, the location of media consortium and their innovation processes have become seen as essential features of agglomeration renewals. In many arenas, academic research as well as policy-orientated projects have focused on understanding the factors operating the re-organization of new media and their development in particular major cities and their agglomerations. There are an increasing numbers of case studies that have investigated particularly remarkable media clusters (Achtenhagen and Picard, 2011; Davis and al. 2009; Picard, 2008 \& 2010; Von Streit and al. 2010) which are used as either exemplary model of developments or starting to question traditional industrial and economic growth policies. In this paper, we will not address the policy implication of media cluster. We rather want to bring some preliminary reflection on media cluster, the dynamic of knowledge and agglomeration. We think it is premature to develop planning policies on cluster when the main issue remains to identify properly the role of knowledge dynamics and its economic implication in both the constitution of media clusters and agglomeration economies. To this moment, it seems unclear to what extent we are able to draw the right lesson of the accumulations of cases on the innovative performance of media clusters. In other words, we think that they are still space to investigate conceptually and/or empirically appropriate analytical tools and knowledge bases on media clusters. Studies on media cluster are relatively recent undertaken. One of the lines of study we pursue in this paper is to what extend the Jacobian model of cities growth dynamics is an appropriate framework to think about media clusters and sector specific knowledge change. In order to explain the issue of knowledge dynamics in media cluster, it is necessary to consider the nature of new knowledge 
created in new media industry and identify the best way we can clusters of the cultural industry.

Currently McCann's classification of industrial clustering (1995, 2001, 2004, 2008) is offering a comprehensive overview of cluster's types, either Marshallian type of agglomeration which he calls the model of pure agglomeration, the Weberian type of cluster which is the industrial complex cluster and the social network model of cluster which specifies type of relations between agents in a network. If those agents are firms, then relation types can vary through joint venture, lobbying informal alliance and reciprocal arrangements. Scott (1988) developed a geographical version of social networks by working out the model of "new industrial areas". It aims at describing the characteristics and performance of industrial region. Researches distinguish between the old industrial area such as Italy's Emilia-Romagna and new industrial area such as Silicon Valley (Scott, 1988; Saxenian, 1994; Castells \& Hall, 1994). There are varieties of research that work out the new and old social network theory in the direction of social capital, creativity and space (Glaeser et al. 2000; Glaeser et al. 2002, Caves, 2000; Davis et al. 2012; Florida 2002; 2005; Scott, 1998a, 2000).

It seems that the model of pure agglomeration would just fit the new media cluster. Despite its unavoidable importance, notably in the study of the dynamics of productivity, it isn't the best theoretical instrument for media cluster analysis. The Marshallian model assumes that clustering happens by localized external agglomeration economies. In this model, there are positive agglomeration externalities, i.e. local information and knowledge spillovers, nontraded local input and skilled labour pool. There are partial elements to consider and some to leave aside (Karlsson, $2008 \mathrm{a} \& \mathrm{~b}$ ). For that matter, let us review the existing literature developing the Marshallian model in different ways. The first one is called the MarshallArrow-Romer (MAR). This line of thought looked at what I would called the "increasing 
return theory of productivity" which assume that increasing returns play an essential role in the explanation of sustained growth (Krugman, 1991a\&b). One of the refinements of the same principle is the "learning by doing" taking place within a single location (Glaeser et al. 1992). We are inclined to think that the endogenous theory of productivity is an imperious necessity in contemporary studies of innovation and wealth creation (Shapiro, 2005). Nevertheless, concerning the study of media cluster, we will logically prefer the second alternative of the pure agglomeration model proposed by the "new economic geography" (Fujita et al. 1999; Fujita and Thisse 2002) and more traditional approaches of urbanization theory such as Jacobs (1969; 1984). This second branch of the pure agglomeration theory presents the clear advantage to deal with agglomeration diversity-variety in relationship to the dynamics of knowledge. In the "new economic geography", the diversity thesis suggests that inter-industry spillover (Ferrando and al. 2008) is generally more important than inter-industry effects (Pandit and al. 2002) to explain growth. As far as the theory goes, the variety version of agglomeration theory is our starting point. We will narrow it down in light of the sectorial characteristics of the new media industry.

The model of "new economic geography" stipulating diversity as a central component of the clustering phenomenon is still grounded on the idea that knowledge and information sticks to particular clustered localities. Although this is partly true for the media cluster, these are an essential part of the story missing. Beside the problem of measuring "knowledge", the media cluster assumes both the stickiness of knowledge and the knowledge flows to the cluster. To be more precise, the geographic location of cultural industries comprises a selective concentration of media industry in large cities and metropolises organized in clusters (Scott, 2000; Braczyk, Fuchs \& Wolf, 1999; Krätke, 2002; Krätke \& Taylor, 2004). Beside the aspect of clustering, some key players in this industry are also multinationals with a global cultural 
presence (Morley \& Robins, 1995; Robins, 1995; Pratt, 2000; Held et al., 1999; Karlsson and al. 2010; Scott, 1998b). Those globalized consortium work with a worldwide network of subsidiaries and other branch offices. They constitute a network of urban cluster of cultural production. Both their localized cluster and their global metropolitan networks are the core of their cultural production. Both flow of knowledge maybe considered contradictory according to the Marshallian pure agglomeration theory.

For that reason, we find it necessary to reconsider essential elements of the new media industry having in mind a tailor made dynamics theory based on metropolitan cities. As it is well known in economics, the issue of knowledge capture is a recurrent issue forcing us to work with stylised constructs, proxies and other conceptual ideal types. In addition, clearly, we are facing the same problem here when dealing with both knowledge dynamics in the creative industry and agglomeration effects. The existing literatures on creative industry (D. E. Andersson \& Å E Andersson, 2008; Camagni, 2012; Karlsson, 2010; Power \& Scott, 2004; Scott, 1997, 1999, 2000a\&b; Zukauskaite, 2010) and media clusters (Cook and Pandit, 2008; Karlsson \& Picard, 2011; Achtenhagen \& Picard, 2011) offer partial but essential parts of the puzzle. Scott (2000a) captures it nicely with the concept "multi-faceted industrial complexes". To start unfolding this puzzle posed by "multi-faceted industry", we will address the media industry by looking at (1) the advent of information technology in the new media sector creating a "weightless economy", (2) the key characteristics of media clusters, (3) a Jacobian metropolitan model of media cluster and (4) concluding on further empirical issues.

\section{New media's "weightless economy"}


Economic geographers have accepted to a high extent the economic analysis of clustering processes. They have done so stressing that social, cultural and institutional factors also play an important role for clusters to develop, grow, possibly decline, and disappear (Martin \& Sunley, 1996). Scott (1998b) claims, for example, that clusters can only create new knowledge and new products and continue to grow if they have linkages with external markets and utilise a mix of local and non-local transactions. Thus, the effects of local interaction and learning are much stronger if they are continuously supported by impulses from other regions and clusters (Bathelt, 2005). In other words, economic geographers have well perceived the tension between local and global economies within some kinds of clusters. To address this tension in their studies, they have taken a classificatory approach (Potts \& Cunningham, 2008). For example, Bathelt, (2005) has suggested analysing clusters along five dimensions: i) the vertical dimension, ii) the horizontal dimension, iii) the power dimension, iv) the institutional dimension, and v) the external dimension. Far from denying the multilayered structure of transactions taking place within and between clusters, we are not inclined to think that large classification scheme will help solving the issue of catching diversified "knowledge content".

Some more promising venture in this domain should come from the reflection on technological change affecting media clusters. Today developments within information and communication technologies (ICT) stimulate the birth of new media services including the creation, manipulation and distribution of digital content (Gillespie, Richardson \& Cornford, 2001). An interesting characteristic of these new services, which include software, databases, electronic libraries, new media, videos, broadcasting, etc., is that they do not just embody knowledge - they are knowledge and behave as such (Arrow, 1962; Feldman, 1994). 
These new services represent what Quah (1999) calls "the weightless economy"3, i.e., an economy whose products are non-excludable, infinitely replicable and electronically transportable costless through space. Similar to Arrow (1962) definition of knowledge, this observation could lead to the conclusion that the location of the production of media products is a non-issue. Since there are no raw materials that should be transported to the producers and no physical goods that should be distributed from the producers to the customers, media firms could locate anywhere. Urban regions would no longer host any clusters of media firms. So why do media firms continue to cluster?

The development of "the weightless economy" is not subtractive of existing economies, but enhancing them through diversification and replacement. To reach this conclusion, we observe tendencies of technology-related industry convergence (Rosenberg, 1963; Sahal, 1985; Dosi, 1988) in the emerging digital economy. There is indeed a breakup of old value chains (Ewans \& Wurster, 1997) followed by a new structuring of value chains, where takeovers and strategic alliances play a significant role (Hagel III \& Singer, 1999) ${ }^{4}$. There are today numerous claims that industries like telecommunications, computing and entertainment are converging. This does not mean that those industries will constitute

\footnotetext{
${ }^{3}$ Quah (1999) indicates that "weightless economy" maybe also called "knowledge economy", "intangible economy", "immaterial economy" or the "new economy". Kling \& Lamb (2000) suggest that the term of "information economy" include all informational products such as publishing, R\&D, legal and insurance services, entertainment and teaching in all forms. In comparison, "internet economy" addresses only the products whose development, production, sale or distribution is critically depending on digital technologies. Piazolo (2001: 30) defines the digital economy as "an economy where both the modern (digital) information and communication technologies provide worldwide access to almost any available information.”

${ }^{4}$ One example of the breaking-up of the value chains in the media sector is the increasing role of content intermediaries (Hess and von Walter, 2006).
} 
industrial complex in the Weberian or Hooverian sense of the term. It certainly might evolve into one huge multimedia industry (Collis, Bane \& Bradley, 1997; The Economist, 2000) more akin to an endogenous growth of diversified services within metropolises. This industry has received particular attention recently (Brail \& Gertler, 1999; Egan \& Saxenian, 1999). In addition, it is noticeable that such services variety and volume may be best understood in relationship to new media convergence between telecommunications, media and information technology sectors. It is certainly probable that the great growth of services is due to the emergence of the Internet and its subsequent business combination (see table 1 below by Krätke \& Taylor, 2004).

\section{[Table 1 here ]}

Those combinations have increased the capability of existing networks to carry both telecommunications and broadcasting services (Knieps, 2003). Developments in digital technologies and software are creating a large innovative technological potential for the production, distribution and consumption of information services. Convergence, characterised as the ability of different network platforms to carry essentially similar kinds of services, may have very different faces: telecommunications operators may offer multimedia systems over their networks; broadcasters may provide data services over their networks, cable operators may provide a range of telecommunication services, etc.

A cursory look at Krätke \& Taylor's table above suggest that the positive differential between service and media ranking confirm the role of metropolises and urban agglomeration such as London, New York, Paris, Milan, Los Angeles, Toronto, Madrid, Amsterdam, Sidney and Zurick. There is increasing evidence that the digital revolution actually reinforces the 
position of leading urban regions (Castells 1989, 1996; Hall 1998; Wheeler et al. 2000). So why media firms do cluster, when the technological opportunities have seemingly reduced the necessity of proximity in operations between inter-linked firms $?^{5}$ Actually, it seems as if the clustering tendencies are even more dominant in media industries than in many traditional industries. Ogawa (2000) shows, for example, that ICT development may not necessarily encourage the dispersal of economic activities due to the network and technology effects of ICT infrastructure supply. Cities are a means of reducing the fixed travel costs involved in face-to-face interactions. Empirical results show that telecommunications complement them rather than exclude them (Gaspar and Glaeser 1998).

ICT has an effect of enhancing exponential efficiency of transactions both in kind in cost. ICT rapid diffusion reduced dramatically transport and communication costs altering the incentives for clustering of media industries as well as other industries. It is too early to observe the results of the diffusion of ICT but it is possible to identify some possible effects (Venables, 2001). ICT reduces:

\footnotetext{
${ }^{5}$ In the 1980s and early 1990s, some cyber prophets and technological optimists predicted that the emergence of the digital economy would kill distance and make clustering in urban regions superfluous (Cairncross 1997; Knoke 1996; Naisbitt 1995; Negroponte 1995; Toffler 1980) and at the same time eliminate the scale disadvantages of smaller and more peripheral regions. The basic idea was that the spread of the use of ICT has the potential to replace face-to-face activities that formerly occurred in central locations. This alone would strongly reduce or even eliminate agglomeration economies and hence make economic activities very "foot-loose". At the beginning of the 21 st century, however, it has become clear that this picture is at least single-sided. New technologies are likely to remain grounded in existing urban regions, which imply that these regions will keep their locational attractiveness and that clusters will remain or even grow. In other words, ICT has not rendered work and organisation "space less" (Neff, 2005).
} 
- The search and matching costs in product markets but closeness by customers may still be essential, in particular for products with rich and fluent characteristics.

- The direct shipping costs since many products can be delivered in digital form.

- The control and management costs for geographically and organisationally fragmented operations.

- the cost of time in transit, i.e. the shipping to and communication with distant locations.

- the costs of personal interactions but knowledge spillovers are stimulated.

- the costs of commuting and of travelling in agglomerations.

- the costs of replicating products and

- the costs of relocation.

These effects are not media-sector specific but apply to it. Furthermore, due to the cultural character of the media sector's products, ICT might have stronger effects on it than on other sectors. It is by no means statistically clear how significant these factors are in affecting the clustering in the media sector. Nevertheless, it seems that ICT plays an essential part as a multiplier in the contemporary diffusion of cultural services. It simply increases the number and variety of producers' services. We do not have a clear solution for appreciating the role of ICT in productivity enhancement of media cluster since media firms add to their existing physical value chain a virtual one having the effect of eliminating stages in the value chain itself (Benjamin \& Wigand, 1995; Ghosh, 1998, Bugge, 2010). As a result, we are clearly left with an empirical issue to solve. A question remains: how the 
clustering of media sector functions as a multiplier of differentiated services?

\section{Key characteristics of media clusters}

Clusters exist when there is a large enough concentration of media (and related) firms in a city or a metropolitan area. Several firms are normally gathered in a specific, often central location in the city, but the cluster may include other firms in the surrounding area ${ }^{6}$. An important characteristic of clustering is that the firms share resources, such as labour, contract services, information and knowledge, and interact directly or indirectly for mutual advantage and benefit. Those are some of the several obvious reasons to why media firms tend to cluster $^{7}$.There is today a growing body of literature dealing with media clusters and in particular with large media clusters (van den Berg, Braun \& van Winden, 2001), sometimes

\footnotetext{
${ }^{6}$ At the fundamental level, media differ because they involve a complex interplay among cultural, economic, and political objectives. In media cluster development, issues of national and regional identity, language, and culture play significant roles, as well as desires to promote domestic content production to counter foreign content.

${ }^{7}$ The media industry organized itself in cluster in order to be able to manage the high degree of interaction among individual firms in short-project cycles, among large amount of specialities in order to produce diversified content. Those clusters have significant networks in the agglomeration and with national and international players. Media industries are organized in a specialized form of cluster designed to produce mediated content, such as motion pictures, television programs/videos, broadcasts, audio recordings, books, newspapers, magazines, games, photography and designs, websites, and mobile content for customers often are based elsewhere. These clusters may have significant relations with other industries and clusters such as cultural industries (music and theatrical performance; museums and heritage sites; festivals), sports and entertainment activities (professional sports teams and venues and amusement parks), information and communication technologies (computers, software, telecommunications), and hardware manufactures (television and radio receivers, set-top boxes, game consoles, DVD players, etc.).
} 
characterized as "global media cities" (Krätke, 2003).

[ table 2 - here ]

As mentioned in the introduction, spatial industrial clustering prevails within the media sector especially in the form of agglomeration economy. However, one interesting question concerns the qualification of distinctive aspects of the media sector. As identified through its weightless economy, media clusters' special traits are guided by fluid value chain grounded in large agglomerations and having global reach. To be more specific, there are clearly metropolitan characteristic of media products, such as their public goods character, the scale economy of media production, its important circuits of distribution, its high degree of product differentiation, its interdependency with advertising content ${ }^{8}$, and the existence of network externalities (Rosse \& Dertouzos, 1978 \& Rosse 1979; Owen \& Wildman, 1992). Following is a review of the main characteristics of media clusters, namely (1) the role of creative activities, (2) the rapid evolution of its products, (3) the organisation of labour in intra-inter projects structure, (4) the presence of large media oligopoly and (5) the clustering of young firms as service suppliers.

\footnotetext{
${ }^{8}$ Media's economic activities have a strong advertisement component. They are directed towards entertaining and informing, seeking to reach and influence a large audience. According to a traditional communication theory, it involves a sender signalling a typically large numbers of receivers (audience), where the relationship between them is one-directional and impersonal (Vogel, 1990). However, the existence of onlinecommentaries, letters to the press, web-based debates, phone-in-programmes, chat-pages, blogs, etc. have radically changed the role of the sender of information. See for example, the issue confronted by the UK newspaper the guardian http://www.economist.com/node/21563334 The output of the media activities has to be distributed to the widest possible audience, in order to maximise the returns on investment, making the distribution function a critical determinant of economic success (Vogel, 1990).
} 


\section{1- Creative activities}

Because many of the media industries are creative industries, they are within or closely related to the cultural sector. The tendency of creative cultural industries to clusters has been documented in the literature in recent decades (Scott, 1997; Hitters \& Richards, 2002; Mommaas, 2004). One important and fundamental characteristic of the media sector's many activities is its relation with creative activities. There is a constant need for creativity and innovation in the design and development of their productions. Each output is a "one-off" item, which must be experienced by consumers as new or different, even if minimally. Thus, the creation of media output is heavily dependent upon small groups of talented people: books' authors, actors' crew in film, musical bands, copywriters and designers of advertising, etc. It is well known that creative activities only develop in specific milieu characterised by diverse activities and competencies with synergetic potential, instability and uncertainty, great tolerance, and critical mass (Andersson, 1985). Such milieus are normally found only in large cities.

\section{2- Rapidly evolving}

Another important characteristic of media products is that the short product cycles of cultural content. It implies that important external advantages and stimuli are derived from the incentives of the media firms itself to generate competing goods and services (Maskell, 2001; Malmberg \& Maskell, 2002). Creative firms in media industries cannot reproduce indefinitely earlier products limiting the advantage they could take from rent economies. Their ability to generate new products is directly related to their ability to compete in the cultural market. This market is made of customers' choice for visually and functionally novel and/or superior offerings to earlier products. This implies that it is critical for firms in 
media industries to actively monitor the products of their competitors, and transform and improve their own products accordingly. Presence for a media firm in a cluster with other media firms nearby makes it easier to formally and informally monitor and study the production of others. This kind of monitoring is an important part of the creative process, which stimulates innovation, imitation and competition ${ }^{9}$ (Britton, 2007). Innovation in media industries is often incremental and requires new combinations or applications of existing tacit and/or codified knowledge building upon past creative successes and an expanding skill base (Wolfe, Davis \& Lucas, 2005).

\section{3- Intra-inter projects}

A third important characteristic of the activities in important parts of the media sector is their organisation in intra- and inter-firm projects. The production networks are set up on a limited time span as a temporary project-based ${ }^{10}$. This type of governance is a solution to the issue of coordinating of production known in the literature as flexible specialization (Piore \& Sabel, 1984; Storper, 1997; Storper \& Harrison, 1991; Storper \& Venables 2004) which is very common in the media sector (Starkey, Barnatt \& Tempest, 2000; Sydow \& Staber, 2002; Mossig, 2004; Ferriani, Corrado \& Boschetti, 2005). The flexible specialization model makes it possible for the leading media firms to use the freelancers and the different small

\footnotetext{
${ }^{9}$ Competition in media market is achieved by product differentiation (Rosse \& Dertouzos, 1978a). To avoid head-to-head competition in homogeneous markets, media firms engage in Hotelling-type competition to distinguish their content products (Hotelling, 1929). The maximum number of differentiated products in monopolistically competitive markets is determined by exogenous variables, such as market size, distribution of taste groups, size of entry barriers, operation costs, etc. Those are difficult for individual media firms to influence (Mankiw and Whinton, 1986; Waterman, 1990).

${ }^{10}$ Many of the media sector products, like films, are produced in the form of projects, which run for limited periods.
} 
firms in the media cluster as a reserve labour pool and to reduce risks by relying to a high extent on short-term contracts (Christopherson, $2005 \&$ 2006). Project-based production is true for film production, music production, book production, software development, etc. Authors (Grabher, 2002; Pratt, 2002) have suggested that such project-based enterprises are the archetypical form of the emerging new media industries, as well as of many industries in the cultural sector. Thus, the single talented individual or small group of people are part of a larger production network using a varied supply of specialists. In software development, continuous updating of software demand the employment of large in-house as well as outsourced teams of designers and managers, preferably with good opportunities for frequent face-to-face communication (Cusumano, 1991; Cusumano \& Selby, 1996). Hansen, VangLauridsen \& Asheim (2005) stress that in the entertainment sector, production systems often are based upon the assembling of new teams of actors, writers and other specialised workers for each new project. Carefully selected staff from different firms ${ }^{11}$, which, for a limited period, dedicate some or all their time to the tasks specified for the project, constitute such inter-firm projects. These inter-firm projects are based upon a rigorous division of labour within the production chain, i.e. vertical disintegration, and a specialisation in small areas of production.

\section{4 - Group of large global media oligopoly}

A fourth important characteristic of the media industry is the existence of a group of large global media oligopolists (McChesney, 1999), strategic alliances between such oligopolists and mergers and acquisitions. One common picture of industrial clustering is the co-location of many small firms in the same locality. Recognising the importance of large

\footnotetext{
${ }^{11}$ These firms are overwhelmingly made up by small businesses, micro-businesses and self-employed free lancers, which can be described as dependent entrepreneurs (Burton-Jones, 1999).
} 
global actors in the industry makes it necessary to think differently about media clustering. Obviously, large anchor media firms may play a critical role for the clustering of small and medium-sized media firms. To discuss the anchoring role of global media oligopolists in the clustering of media firms, it is necessary to discuss some important characteristics of these firms (Chan-Olmsted \& Chang, 2003):

- They offer dual, complementary content and distribution services of media products.

- They rely on dual revenue stream from consumers and advertisers.

- Most media content products are non-excludable and non-depletable public goods. Its consumption by one individual does not exclude another individual to consume it. Instead, mass consumption adds to scale economies in production.

- Many media content products are marketed under a windowing process. Distribution of a specific content is delivered to consumers via multiple outlets sequentially in different periods.

- Media products are highly subjective to the cultural preferences and dependant to the existing communication infrastructure of each geographical market. It includes the regulatory control imposed in different countries.

Today large media firms play a strategic role in the production and delivery of media products. For example, only global firms can afford to deal with the multiple-levelled legal involved in trade barriers, distribution exclusivities and other content repackaging to dub or censor. Ultimately, it implies that corporate structure, strategy, management, and behaviour 
can have a significant influence on industrial clustering of media firms (Fu, 2003, Hendriks, 1995).

\section{5- Fairly young firms in clusters}

A fifth important characteristic is that the firms in media clusters reveal a number of common characteristics (Scott, 1996; Brail \& Gertler, 1999; Egan \& Saxenian, 1999; Bathelt, 2001). Most of the firms in these clusters are young but often serve older, larger, established media firms. Often existing only for a few years, they supply high-specialised services. They are normally small in terms of employment. The local growth processes of many of the media clusters are driven by innovative regional start-ups. Teams of entrepreneurs rather than individual entrepreneurs play the role of "embryonic city economy" in Jacobs' term. They relied heavily on owner capital. These clusters emerge in inner cities rather than in suburban locations (Storper \& Christophersen, 1987; Eberts \& Norcliffe, 1998; Brail \& Gertler, 1999).

The five characteristics of media clusters are based on the ability of media firm to use local producer of services. In the same time, they use the metropolitan markets to have access to a large pool of services suppliers, which allows them to build a reasonably complete work organization. It allows the clustered media firms to use local suppliers without locked-in dependence toward them. There is clearly a homology between the advantage of cities and the media clusters in the way they can use their rooting in agglomeration to project themselves in global exporting ventures. For that matter, it is necessary to explicit further, how a Jacobian model of the metropolitan economies can explain the dynamics of media clusters.

\section{Toward a Jacobian metropolitan model of media clusters}


There are a series of similarities between the way large cities are generating what Jacobs calls an "explosive growth" and the way media cluster are behaving. Both successful media clusters and cities have benefited from each other through the enlargement of their local market but their ability to generate global exports (Fuchs, 2002). In this section, we will review some of the advantage large agglomeration brings to the creative milieu necessary to support a vibrant media clustered industry. The interplay between media cluster and agglomeration economies leads us to consider the Jacobian model of cities' economies. We propose to revisit media cluster in the light of Jacobs" "reciprocating system of city growth" (1969). This system explains the innovation process thanks to two stages. The first stage (fig. 1 called "metropolitan system") shows how an agglomeration can reach a critical size thanks to its production and exportation of goods and services. In turn, the growing importation is an engine to renewing the production. The second stage (fig. 1, called "the global system") is the logical extension of the first one through intensified import replacement, which allows the development of global versatile export. In turn, this global export increases the scale and scope of importation, which affect accordingly the replacement of import. In Jacobs' research, only large cities are able to generate a diversity of human activities and interests that continually create streams of public goods. In other words, it sustains the workings of what Scott calls "the creative milieu". Socialization dynamics ensure the preservation and development of local knowledge under the exposure of global information and knowledge flows. Hence, the clustering of producers in the new media field should occur "where new communications technologies are insufficient to capture the full range of human expression ... clustering of producers will ... occur in particular places, namely those that afford a large degree of chance and random encounter with both similar and 
different producers, and users" (Pratt 2000: 429). Large cities also offer "institutional thickness" (Amin \& Thrift, 1995) overlapping webs of supporting organizations ${ }^{12}$, such as financing organizations, chambers of commerce, local and regional authorities, marketing, innovation and business support agencies that "create synergy, and a collective sense of identity and purpose within a cluster" (Bassett, Griffiths \& Smith, 2002). These features and the fact that media production requires the overlapping skills of a highly differentiated workforce (Pratt, 1999) imply that full-blown media clusters are normally only present in large cities.

Urban media clusters with both strong intra-regional and strong global networks are essential to explain their innovation dynamics. They have the potential to become worldwide forerunners because the critical mass they have acquired from their growing activities in metropolises allows them to develop versatile exports. Whereas strong intraregional networks facilitate competitive and creative production, global networks provide inputs of external knowledge and access to distant markets. They have an innovative function, which is to reduce the risks urban media clusters from becoming inflexible. Therefore, a combination of strong intra-regional and strong global networks offers the most favourable conditions for an enduring ability and capacity to secure the long-term competitiveness of urban media clusters (Storper \& Harrison, 1991; Freeman, 1995; Marcusen, 1996; Freeman \& Soete, 1997; Ernst, 1999). Here is a revised schematic of Jacob's combination of metropolitan local market with media cluster's ability to export globally.

\footnotetext{
${ }^{12}$ Amongst those institutions, key infrastructures are schools, colleges, universities and training centres. They secure a continuous supply of skilled and specialized labour. Public-private partnerships promote urban renewal and certain technological, creativity and innovation schemes.
} 
[Figure 1 here ]

The media value chain is continuously changing not least due to organizational and technological changes including an increasing digitalization but also due to changes in transport costs and distribution systems ${ }^{13}$. Seen from a growth perspective, this implies that characteristics of functions within the media sector (ICT, flexible specialization and high diversity, etc.) are not only out-sourced but often also relocated from media clusters to other locations nationally but also increasingly internationally, i.e. offshored (global distribution and diffusion, advertising, oligopoly, alliances etc.). However, many media functions continue to be clustered irrespectively of technological changes and reductions of transport costs and some media functions might over time even become more clustered. The Jacobian model of media cluster proposed above is articulating explicitly the fact that urban clusters can never be studied successfully without considering their inter-regional, national and global connections ${ }^{14}$. The increased importance of global links does not imply that the intra-regional links in clusters lose their importance. What is

\footnotetext{
${ }^{13}$ Driver \& Gillespie (1993), in their study of printed magazines in the UK, show that the creative tasks of conception, design and editorial as well as the preliminary production stage of typesetting and reproduction remained firmly tied to London while the printing of magazines was decentralized from London.

${ }^{14}$ Many authors have not fully understood the Jacobian model misrepresenting what globalization implies for firms and regions. They take the globalization process to be morally negative in fading the national cultural identities through an increasing of geographical mobility, the worldwide migration and the resulting ethnic hybridization and apparent cultural homogenization (Zukin, 1995). Some authors have argued that due to the rapid advance of globalization, economic structures and flows are increasingly becoming disembedded from regional contexts. Hence, they conclude that regional embeddedness is losing its importance (Thurow, 1996).
} 
important for urban media clusters is that they succeed in combining high quantity and high quality intra-regional networking with high quantity and high quality global networking. Certainly, successful urban media clusters need to preserve strategic positions in the organizational structures and networks of global players but this is impossible if the intraregional networking is not of a high quantity and quality.

At the bottom, the interrelation between the media clusters based in metropolitan cities and their international reach is explained by the dynamics of economic growth. Jacobs' model explains how media clusters are able to function as import replacing multipliers. They generate versatile export, which in turn add-up to the global export capabilities of clusters. To specify a little further this virtuous circle, let us look at the linkage between media cluster industry anchored in metropolises and their global reach. Media clusters are anchored in metropolises because they create a number of projects that engage a large number of different specialists on a temporary basis. Only a relatively large cluster will offer a diverse enough supply of specialists to make such projects economically feasible. Further, they do not always restrict their activities to the local economic milieu. Because of global competition and the need to serve demand elsewhere, media clusters are able to take advantage of economies of scale. Some media firms extend the geographical scale and scope of their external linkages (Nachum \& Keeble, 2003). One important aspect of globalization is the continuous scaling-up of markets and the increasing growth of transnational financial and economic networks (Sassen, 1994; Waters, 1995). The critical challenge for urban media clusters is to secure enough synergies between the global and the intra-regional networks to expand import-replacing multipliers in order to add export multiplier. Urban media clusters that successfully secure these synergies might be characterized as global media clusters (Sassen, 1994). Successful global media clusters are those whose networks 
incorporate an adequate supply of quality knowledge, creativity and design resources. This can only be achieved with the ability, willingness and openness of local firms to cooperate with global firms to make use of external global sources of inspiration, information, knowledge and creativity. Media firms' clear focus on the combination of local and global resources systems is certainly a key to develop new superior media products.

\section{Further empirical issues posed by the Jacobian innovation process}

As suggested by the research in regional economics (Blien \& Maier, 2008), urban regions and large agglomerations in particular are engines of creative activities, innovation and subsequently source of economic growth. The question that media cluster poses to the economics of innovation is double: 1. What the Jacobian model of agglomeration growth says about media cluster's innovation? 2. How urban economists will empirically account for the intense knowledge concentration, culture creation and service transactions taking place in media clusters?

Media clusters research faces many challenges ahead including a better comprehension of the social and economic processes underlying its economic development. We think that the Jacobian model of urban media cluster offers several advantages over existing Marshallian, Weberian or social networks models. We nevertheless are well aware that empirical challenges to make this model work are still ahead of us. Let us review its advantages and outline further research needed along the following four topics:

1. Defining the media economy. Researchers are continuously working on defining the media economy (Gibson \& Kong, 2005, O’Regan, 2011), since many are ad hoc and 
because on-going technological and structural changes modify continuously its borders. Media cluster have fluid relations to other sectors in the economy and to the consumers. It makes the adoption of traditional Weberian cluster irrelevant and the Marshallian in need of a strong specification. Other approaches have emerged trying to capture an industry based on cultural services thanks the sectorial approach, the labour market and organization of production approach (Scott, $1996 \& 2001$ ), the occupational approach (such as the creative class approach a la Florida (2002), and the convergence of formats approach (Gibson \& King, 2005). This diversity of perspectives calls for a comprehensive framework reconceptualising the relation between creative economy and the city (Pratt \& Hutton, 2012).

2. Our solution is a Jacobian definition of urban media clusters based on her metropolitan economics. The central element of analysis is Jacobs' (1969; 1984: 193) proposition to consider the city as a creative knowledge economy:

"Cities (...) vital functions are to serve as primary developers and primary expanders of economic life, functions that work not in the least like perpetual motion. They require continually repeated inputs of energy in two specific forms: innovations, which at bottom are inputs of human insight; and ample replacements of imports, which at bottom are inputs of the human capacity to make adaptive imitations."

One can see how Jacobian urban media clusters can be conceived as creative clusters (Landry \& Bianchini, 1995). Jacobs identified well the relevance of tertiary activities at the urban level (Jacobs, 1969, 1984, Simmies, 2002). Without the foresight given to us by the development of new information, multimedia and telecommunications technologies, her 
approach brings two essential insights on the role of knowledge in innovation: 1- Jacobs' definition of "human insight" echoes Hayek's "relevant knowledge" and 2- Jacob's definition of "adaptive imitation" echoes Schumpeter's "new combinations". Jacob's approach of urban centres as "incubating economic life" links more explicitly the urban economics of media clusters with aspects of evolutionary economics accounting for economic development.

3. Jacob's model offers a mechanism to evaluate value-creation in urban media clusters. The superiority of Jacob's model proposed in this paper is to offer a mechanism of evaluation of value creation in media cluster through a genuine economics of socio-cultural knowledge. The strong links between media industries and cultural industries underlines the importance of immaterial assets ${ }^{15}$ in innovation process in this industry. In particular, valuecreation in urban media clusters is connected closely to the existence in the city of specific intellectual resources present in unique creative characteristics through individuals and collective creative processes, as well as through a variety of modes of distribution and consumption (Crane, 1992).

4. The Jacobian model explains endogenously the globalization processes in urban media clusters. Large cities containing media clusters are today dominated by tertiary activities.

\footnotetext{
${ }^{15}$ Hayek (1992: 50-1) gave a definition of "relevant knowledge" proposing to consider the division of knowledge between skills and entrepreneurial ability: "Clearly, there is here a problem of the division of knowledge which is quite analogous to, and at least as important as, the problem of the division of labour. (...) "Skills" refers only to the knowledge of which a person makes use in his trade, while the further knowledge about which we must know something in order to be able to say anything about the processes in society is the knowledge of alternative possibilities of action of which he makes no direct use."
} 
The Jacobian model used to describe its development processes does not led to a stochastic but endogenous characterization of the decline of some factors, a rejuvenation of other and a growth of new ones (Johansson and al. 2001; Scott 1998b). This is the second aspect of innovation contained in Jacobs" "adaptive imitation"16. Jacob's model goes further in the specification of the change of the units of economic analysis themselves. She indicates the mechanics of import and export within urban economics allowing for the articulation of the local and the global level. Further, she specified the dynamics of the urban media clusters showing a distinctive urban tension allowing local systems to produce global services.

\footnotetext{
${ }^{16}$ Schumpeter ([1934], 2007) gave a definition of "new combination" as a fundamental phenomenon of economic development: "It is the producer who as a rule initiates economic change, and consumers are educated by him if necessary; they are, as it were, taught, to want new things, or things which differ in some respect or other from those which they have been in the habit of using. Therefore, while it is permissible and even necessary to consider consumers' wants as an independent and indeed the fundamental force in a theory of the circular flow, we must take a different attitude as soon as we analyse change. To produce means to combine materials and forces within our reach. To produce other things or the same things by a different method means to combine these materials and forces differently. As far as the "new combination" may in time grow out of the old by continuous adjustment in small steps, there is certainly change, possibly growth, but neither a new phenomenon nor development in our sense. In so far as, this is not the case, and the new combinations appear discontinuously, then the phenomenon characterizing development emerges. (...) Development in our sense is then defined by the carrying out of new combinations."
} 


\section{References}

Achtenhagen L. \& R.G. Picard (2011) "Media clusters: development paths and core issues" in C. Karlsson \& R.G. Picard (2011) Media Clusters: Spatial Agglomeration and Content Capabilities, Cheltenham, UK: Edward Elgar, pp. 44-71.

Almeida, P. \& B. Kogut (1997) “The Exploration of Technological Diversity and the Geographical Localization of Innovation”, Small Business Economics 9, 21-31.

Amin, A. \& N. Thrift (1995) "Globalization, Institutional Thickness and the Local Economy", in Healey, P., et al., (eds.), Managing Cities: The New Urban Context, Chichester: Wiley, pp. 92-108.

Andersson, Å.E. (1985) Kreativitet - Storstadens framtid (Creativity - The Future of the Metropolis) Stockholm: Prisma.

Andersson, D.E. and Å.E. Andersson (2008) "Infrastructural change and secular economic development." Technological Forecasting \& Social Change, 75(6): 799-816.

Arrow, K.J. (1962) “Economic Welfare and the Allocation of Resources for Invention", in Nelson, R.R. (ed.) The Rate and Direction of Inventive Activity, Princeton: Princeton University Press, pp. 609-625.

Backlund, A.-K. \& Å. Sandberg (2002) “New Media Industry Development: Regions, Networks and Hierarchies - Some Policy Implications", Regional Studies 36, 87-91.

Bassett, K. R. Griffiths \& I. Smith (2002) "Cultural Industries, Cultural Clusters and the City: The Example of Natural History Film-Making in Bristol”, Geoforum 33, 165177.

Bathelt, H. (2001) “The Rise of a new Cultural Products Industry Cluster in Germany: The Case of the Leipzig Media Industry", IWSG Working Papers 06-2001, Johann Wolfgang Goete-Universität Frankfurt. 
Bathelt, H. (2005) "Cluster Relations in the Media Industry: Exploring the "Distanced Neighbour" Paradox in Leipzig", Regional Studies 39(1): 105-127.

Bathelt, H. \& J.S. Boggs (2003) "Toward a Reconceptualisation of Regional Development Paths: Is Leipzig's Media Cluster a Continuation or a Rupture with the Past", Economic Geography 79(3): 265-293.

Bathelt, H., A. Malmberg \& P. Maskell (2004) "Clusters and Knowledge: Local Buzz, Global Pipelines and the Process of Knowledge Creation", Progress in Human Geography 28(1): 31-56.

Beck, H. (2002) Medienökonomie. Print, Fernsehen und Multimedia, Springer, Berlin.

Benjamin, R. \& R. Wigand (1995) "Electronic Markets and Virtual Value Chains on the Information Superhighway”, Sloan Management Review 36(2): 67-72.

Blien, U. \& G. Maier (eds.) (2008) The economics of regional clusters: networks, technology and policy, Cheltenham, UK: Edward Elgar.

Brail, S.G. \& M.S. Gertler (1999) The Digital Regional Economy: Emergence and Evolution of Toronto's Multimedia Cluster, in Braczyk, H.J., G. Fuchs \& H.-G. Wolf (eds.), Multimedia and Regional Economic Restructuring, London: Routledge, pp. $97-130$.

Braczyk, H.J., G. Fuchs \& H.-G. Wolf (1999) (eds.), Multimedia and Regional Economic Restructuring, London: Routledge.

Britton, J.N.H. (2007) "Path Dependence and Cluster Adaptation: A Case Study of Toronto‘s New Media Industry”, International Journal of Entrepreneurship and Innovation Management 7(2-5): 272-297.

Bugge, M.M. (2010) "Jacobian cluster mutation accross advertising and internet-based market communication", Tijdschrift voor Economische en Sociale Geografie, 102(5): $515-531$. 
Burfitt, A. \& S. MacNeill (2008) "The Challenges of Pursuing Cluster Policy in the Congested State", International Journal of Urban and Regional Research 32(2): 492505.

Burton-Jones, A. (1999) Knowledge Capitalism - Business, Work and Learning in the New Economy, Oxford: Oxford University Press.

Cairncross, F, (1997) The Death of Distance, Boston, MA: Harvard Business School Press.

Camagni. R, (2012) "Creativity, Culture and Urban Milieux" in L.F. Girard, T. Baycan, P. Nijkamp (eds.) City and Creativity: Promoting Creative Urban City, London: Ashgate Publishing, pp. 183-198.

Castells, M. (1989) The Informational City. Information Technology, Economic Restructuring and the Urban-Regional Process, Basil Blackwell, Oxford.

Castells, M. (1996) The Rise of the Network Society. The Information Age: Economy, Society and Culture, Vol. 1, Oxford: Blackwell.

Castells, M. \& P. Hall (1994) Technopoles of the world: the making of 21 century industrial complexes, London: Routledge.

Caves R.E. (2000) Creative Industries: contracts between art and commerce, Harvard: Harvard University Press.

Chan-Olmsted, S.M. \& B-H. Chang (2003) "Diversification Strategy of Global Media Conglomerates: Examining Its Patterns and Determinants", Journal of Media Economics 16(4): 213-233.

Cheschire, P. C., Malecki, E. J. (2004) "Growth, development and innovation: a look backward and forward", Papers in Regional science, 83(1): 249-267.

Christopherson, S. (2005) "Divide and Conquer: Regional Competition in a Concentrated Media Industry”, in Elmer, G. \& M. Gasher (eds.), Contracting Out Hollywood: 
Runaway Productions and Foreign Location Shooting, Oxford, UK: Rowman \& Littlefield, pp. 21-40.

Christopherson, S. (2006) "Behind the Scenes: How Transnational Firms are Constructing a New International Division of Labour in Media Work”, Geoforum 37, 739-351.

Collis, D.J., P.W Bane \& S.P. Bradley (1997) "Winners and Losers: Industry Structure in the Converging World of Telecommunications, Computing and Entertainment", in Joffe, D.B. (ed.), Competing in the Age of Digital Convergence, Boston: Harvard Business School Press, pp. 159-199.

Cook, G.A.S. \& N.R. Pandit (2008) "Clustering in the Broadcasting Industry", in C. Karlsson (ed.) Handbook of Research on Cluster Theory, Edward Elgar, Cheltenham, UK: 274-91.

Crane, D. (1992) The Production of Culture: Media and Urban Arts, Newbury Park, CA: Sage Publications.

Cusumano, M. (1991) Factory Concepts and Practices in Software Development, Annals of the History of Computing 13(1): 3-32.

Cusumano, M. \& R. Selby (1996), Microsoft Secrets, London: Macmillan.

Davis, C.H., T. Creutzberg \& D. Arthurs (2009) "Applying an Innovation Cluster Framework to a Creative Industry: The Case of Screen-Based Media in Ontario", Innovation: Management, Policy \& Practice 11(2): 201-214.

Davis, C.H., J. Shtern, M. Coutanche, E. Godo (2012) "Screenwriters in Toronto: Centre, Periphery and Exclusionary Networks in Canadian Screen Storytelling”, draft RTA School of Media, Ryerson University, Toronto, 30 pages.

Dosi, G. (1988) “Sources, Procedures and Microeconomic Effects of Innovation”, Journal of Economic Literature 36: 1126-1171. 
Driver, S. \& A. Gillespie (1993) "Information and Communication Technologies and the Geography of Magazine Print Publishing”, Regional Studies 27(1): 53-64.

Eberts, D. \& G. Norcliffe (1998) "New Forms of Artisanal Production in Toronto's Computer Animation Industry”, Geographische Zeitschrift 86(2): 120-133.

The Economist (2000) “The Great Convergence Gamble”, The Economist 357: 67-68.

Egan, E.A. \& A. Saxenian (1999) "Becoming Digital: Sources of Localisation in the Bat Area Multimedia Cluster", in Braczyk, H.J., G. Fuchs \& H.-G. Wolf (eds.), Multimedia and Regional Economic Restructuring, London: Routledge: 11-29.

Ernst, D. (1999) “How Globalization Reshapes the Geography of Innovation Systems: Reflections on Global Production Networks in Information Industries", Paper presented at DRUID 1999 Summer Conference on Innovation Systems, Copenhagen

Ewans, P.B. \& T.S. Wurster (1997) "Strategy and the New Economics of Information", Harvard Business Review 78, 71-103.

Feldman, M.P. (1994) The Geography of Innovation, Dordrecht: Kluwer.

Ferriani, S., R. Corrado \& C. Boschetti (2005) "Organizational Learning Under Organizational Impermanence: Collective Ties in Film Project Firms”, Journal of Management and Governance, 9(3-4): 257-285.

Ferrando, J., J.J. Gabszewicz, D. Laussel \& N. Sonnac (2008) Intermarket Network Externalities and Competition: An Application to the Media Industry, International Journal of Economic Theory, 4(3): 357-379.

Florida, R (2002) The Rise of the Creative Class: and How It Is Transforming Work, Leisure, Community and Every-Day Life, New York: Basic Books.

Florida, R (2004) Cities and the creative class, London: Routledge.

Freeman, C (1995) "The "National System of Innovation" in Historical Perspective", Cambridge Journal of Economics, 19(1): 5-24. 
Freeman, C. \& L. Soete (1997) The Economics of Industrial Innovation, $3^{\text {rd }}$ ed., London: Pinter.

Fu, W. (2003) “Applying the Structure-Conduct-Performance Framework in the Media Industry Analysis, The International Journal of Media Management”, 5 (4), 275-84.

Fujita, M., P. Krugman and A.J. Venables (1999) The Spatial Economy, Cambridge, MA: MIT Press.

Fujita, M. \& J-F.Thisse (2002) Economics of Agglomeration: Cities, Industrial location and regional growth, Cambridge, UK: Cambridge University Press.

Fuchs, G. (2002) “The Multimedia Industry: Networks and Regional Development in a Globalised Economy”, Economic and Industrial Democracy 23(3): 305-333.

Gaspar, J. \& E.L. Glaeser (1998) "Information Technology and the Future of Cities", Journal of Urban Economics 43(1): 136-156.

Ghosh, S. (1998) "Making Business Sense on the Internet", Harvard Business Review 76, 126-133.

Glaeser, E.L., Kallal, H.D., Scheinkman, J.A., Shleifer, A. (1992) "Growth in Cities”, Journal of Political Economy, 100(6): 1126-52.

Glaeser, E. L., D. Laibson, and B. Sacerdote (2002) "An economic approach to social capital”, The Economic Journal 112(483): 437-458.

Gibson, C. \& L. Kong (2005) "Cultural Economy: A Critical Review”, Progress in Human Geography 29(5): 541-61.

Gillespie, A., R. Richardson \& J. Cornford (2001) "Regional Development and the New Economy”, European Investment Bank Papers 6 (1): 109-131.

Grabher, G. (2002) “Cool Projects, Boring Institutions: Temporary Collaboration in Social Context”, Regional Studies 36(special issue): 205-214. 
Hagel III, J. \& M. Singer (1999) “Unbundling the Corporation”, Harvard Business Review 77, 133-141.

Hall, P. (1998) Cities in Civilization: Culture, Innovation and Urban Order, London: Weinfield and Nicholson.

Hansen, H.K., J. Vang-Lauridsen \& B.T. Asheim (2005) "The Creative Class and Regional Growth: Towards a Knowledge Based Approach”, Paper presented at "Regional Growth Agendas" conference, Regional Studies Association, Aalborg, Denmark, March 28-31.

Hayek, F. (1945) "Economics and knowledge” in (1992) Individualism and economic order, Chicago: The University of Chicago Press, pp. 33-56.

Held, D. et al. (1999) Global transformations: politics, economics and culture, Stanford, CA: Stanford University Press.

Henderson, J.V. (1986) "Efficiency of Resource Usage and City Size”, Journal of Urban Economics 19(1): 47-70.

Hendriks, P (1995) “Communications Policy and Industrial Dynamics in Media Markets: Toward a Theoretical Framework for Analysing Media Industry Organisation”, The Journal of Media Economics, 8(6): 61-76.

Hess, T \& B. Von Walter (2006) “Toward Content Intermediation: Shedding New Light on the Media Sector", The International Journal of Media Management, 8(1): 2-8.

Hitters, E \& G. Richards (2002) "The Creation and Management of Cultural Clusters", Creativity and Innovation Management, 11(4): 234-247.

Hotelling, H. (1929) “Stability in Competition”, Economic Journal, 39(153): 41-57.

Jacobs, J (1969) The Economy of Cities, New York: Vintage Books.

Jacobs, J (1984) Cities and the Wealth of Nations: principles of economic life, Random House, New York. 
Johansson, B., C. Karlsson \& R.R. Stough (2001) (eds.) Theories of Endogenous Regional Growth - Lessons for Regional Policies, Edward Elgar, Cheltenham.

Karlsson, C. (2008a) (ed.), Handbook of Research on Cluster Theory, Cheltenham, UK: Edward Elgar.

Karlsson, C. (2008b) (ed.), Handbook of Research on Innovation and Clusters, Cheltenham, UK: Edward Elgar.

Karlsson, C., B. Johansson \& R.R. Stough (2005) (eds.), Industrial Clusters and InterFirm Networks, Cheltenham, UK: Edward Elgar.

Karlsson, C., B. Johansson \& R.R. Stough (2009) (eds.) Innovation, Agglomeration and Regional Competition, Cheltenham: Edward Elgar.

Karlsson, C., B. Johansson \& R.R. Stough (2010) "Introduction" in Karlsson, C., B. Johansson \& R.R. Stough (eds.), Entrepreneurship and Regional Development. Local Processes and Global Patterns, Cheltenham, UK, Edward Elgar: 1-27.

Karlsson, C. \& R.G. Picard (2011) (eds.) Media Clusters: Spatial agglomeration and content capabilities, Cheltenham, UK: Edward Elgar.

Kling, R. \& R. Lamb (2000) "IT and Organizational Change in Digital Economies: A Socio-technical Approach”, in Brynjolfsson, E. \& B. Kahin (eds.), Understanding the Digital Economy - Data, Tools, and Research, Cambridge, MA: The MIT Press, pp. 295-324.

Kneips, G. (2003) “Competition in Telecommunications and Internet Services: A Dynamic Perspective", in Barfiled, C.E., G. Heiduk \& P.J.J. Welfens (eds.), Internet, Economic Growth and Globalisation. Perspectives on the New Economy in Europe, Japan and the US, Berlin: Springer, pp. 217-227.

Knoke, K. (1996) Bold New World: The Essential Road Map to the Twenty-First Century, New York: Kodansha. 
Krugman, P.E. (1991a) Geography and Trade, Cambridge, MA: the MIT Press.

Krugman, P. E. (1991b) "Increasing returns and economic geography", Journal of Political Economy, 99(3): 483-99.

Krätke, S. (2002) "Network Analysis of Production Clusters: The Potsdam, Babelsberg Film Industry as an Example”, European Planning Studies, 10(1): 27-54.

Krätke, S. (2003) "Global Media Cities in a World-Wide Urban Network", European Planning Studies, 11(6): 605-628.

Krätke, S. \& P.J. Taylor (2004) “A World Geography of Global Media Cities”, European Planning Studies, 12(4): 459-477.

Landry, C. \& F. Bianchini (1995) The Creative City, London: Demas.

Malmberg, A. \& P. Maskell (2002) "The Elusive Concept of Localisation Economies Towards a Knowledge-Based Theory of Spatial Clustering", Environment and Planning A34(3): 429-449.

Mankiw, N.G. \& M.D. Whinston (1986) "Free Entry and Social Efficiency", Rand Journal of Economics, 17 (spring): 48-58.

Marcusen, A. (1996) "Sticky Places in Slippery Space - A Typology of Industrial Districts”, Economic Geography 72, 293-313.

Martin, R. \& P. Sunley (1996) "Paul Krugman's Geographical Economics and Its Implications for Regional Theory: a Critical Assessment”, Regional Studies, 77(3), 259-292.

Maskell, P. (2001) “Towards a Knowledge-Based Theory of a Geographical Cluster”, Industrial and Corporate Change, 10(4): 921-943.

McCann, P. (1995) "Rethinking the economics of location and agglomeration", Urban Studies, 32(3): 563-77.

McCann, P. (2001) Urban and regional economics, Oxford: Oxford University Press. 
McCann, P. (2004) "Urban scale economies: statics and dynamics", in R. Capello and p. Nijkamp (eds.) Urban Dynamics and Growth: Advances in Urban Economics, Amsterdam: Elsevier, pp. 31-56.

McCann, P. (2008) “Agglomeration economics", in Charlie Karlsson (ed.) Handbook of research on cluster theory, Cheltenham, UK: Edward Elgar, pp. 23-38.

McChesney, R.W. (1999) “The New Global Media”, The Nation, November 29: 11-15.

Miller, P., R. Botham et al. (2001) Business Clusters in the UK - First Assessment Report, A Report for the Department of Trade and Industry (volumes 1,2 and 3), Trends Business Research, University of Glasgow, Cogent Strategies, University of Cambridge.

Mommaas, H. (2004) "Cultural Clusters and the Post-Industrial City: Towards a Remapping of Urban Cultural Policy”, Urban Studies, 41(3): 507-532.

Morley D. \& K. Robins (1995) Spaces of identity: global media, electronic landscapes, cultural boundaries, London: Routledge.

Mossig, I. (2004) “The Networks Producing Television Programmes in the Cologne Media Cluster: New Firm Formation, Flexible Specialization and Efficient Decision-Making Structures”, European Planning Studies, 12(2) 155-171.

Nachum, L. \& D. Keeble (2003) "Neo-Marshallian Clusters and Global Networks. The Linkages of Media Firms in Central London”, Long Range Planning, 36(5): 459-480.

Naisbitt, R. (1995) The Global Paradox, New York: Avon Books.

Neff, G. (2005) “The Changing Place of Cultural Production: The Location of Social Networks in a Digital Media Industry", Annals, AAPSS, 597(1): 134-152.

Negroponte, N. (1995) Being Digital, Vintage Books, New York.

Ogawa, H. (2000) “Spatial Impact of Information Technology Development", The Annals of Regional Science, 34(3): 537-551. 
Oinas, P, (2002) "Competition and collaboration in interconnected places: towards a research agenda", Geografiska Annaler: Series B, Human Geography, 84(2): 65-76.

O'Regan, T. (2011) "Styles of national and global integration: charting media transformation in Australian cities", Studies in Australasian Cinema, 5(3): 223-238.

Owen, B.M. \& S.S. Wildman (1992) Video Economics, Harvard University Press, Cambridge, MA.

Pandit, N.R., G.A.S. Cook \& G.M.P. Swann (2002) "A Comparison of Clustering Dynamics in the British Broadcasting and Financial Services Industries", International Journal of Economics and Business, 9(2): 195-224.

Piazolo, D. (2001), The Digital Divide, CESifo Forum 2, No. 3: 29-34.

Picard, R.G. (2008) "Media Clusters: Local Agglomeration in an Industry Developing Networked Virtual Clusters", Working Paper 2008-3, Jönköping International Business School.

Picard, R.G. (2010) The Economics and financing of Media Companies, 2d ed. New York: Fordham University Press.

Piore, M.J. \& C.F. Sabel (1984) The Second Industrial Divide : Possibilities for Prosperity, New York: Basic Books.

Power, D. \& A.J. Scott (2004) "A Prelude to Cultural Industries and the Production of Culture", in Power, D. \& A.J. Scott (eds.), The Cultural Industries and the Production of Culture, London: Routledge, pp. 3-15.

Power, D. (2011) The Creative and Cultural industries, The European Cluster observatory: Priority sector report, European Commission, Entreprise and industry, Europa Innova, paper no. 16, Uppsala University.

Potts, J. \& S. Cunningham (2008) "Four Models of Creative Industries", International Journal of Cultural Policy, 14(3): 233-247. 
Pratt, A.C. (1999) Digital Places, London: London School of Economics.

Pratt, A.C. (2000) "New Media, the New Economy and New Spaces", Geoforum, 31(4): 425-436.

Pratt, A.C. (2002) "Hot Jobs in Cool Places: The Material Cultures of New Media Product Spaces: The Case of the South of Market, San Francisco", Information Communication and Society, 5(1): 27-50.

Pratt, A. C. \& T.A. Hutton (2012) "Reconceptualising the relationship between the creative economy and the city: learning from the financial crisis", Cities: Special Issue on the creative economy and the financial crisis, in press.

Scott, A. (1999) “The Cultural Economy: Geography and the Creative Field", Media, Culture and Society, 21: 807-817.

Quah, D. (1999) “A Weightless Economy”, The Unesco Courier, Summer 4(2): 30-32.

Robins, K. (1995) “The New Spaces of Global Media”, in Johnston, R.J., P.J. Taylor \&

M.J. Watts (eds.), Geographies of Global Change. Remapping the World in the Late Twentieth Century, Oxford: Basil Blackwell: pp. 232-47.

Rosenberg, N. (1963) “Technological Change in the Machine Tool Industry, 1840-1910”, The Journal of Economic History, 23(4): 414-446.

Rosse, J.N. \& J.N. Dertouzos (1978) "Economic Issues in Mass Communication Industries", in Proceedings of the Symposium on Media Concentration, Volume 1, Washington, D.C.: Federal Trade Commission, pp. 40-192.

Rosse, J.N. (1979) "The Evolution of One-Newspaper Cities", in Federal Trade Commission, Proceedings of the Symposium on Media Concentration, Volume 3, Washington, D.C. : Federal Trade Commission, pp. 429-471.

Sahal, D. (1985) “Technological Guideposts and Innovation Avenues", Research Policy, 14(2) 61-82. 
Sassen, S. (1994) Cities in a World Economy, Pine Forge Press, Thousand Oaks, CA.

Saxenian, A-L. (1994) Regional Advantage: Culture and Competition in Silicon Valley and Route 128 Cambridge, MA: Harvard University Press.

Schumpeter, J. (1934) The Theory of Economic Development: An Inquiry into Profits, Capital, Credit, Interest and the Business Cycle, New Brunswick, USA: Transaction Publishers.

Simmie, J. (2002) "Trading places: competitive cities in the global economy", European Planning Studies, 10(2): 201-14.

Scott, A.J. (1988a) New Industrial Spaces, London: Pion.

Scott, A.J. (1988b) Metropolis: From the Division of Labor to Urban Form, Berleley: University of California Press.

Scott, A.J. (1996) "The Craft, Fashion, and Cultural-Products Industries of Los Angeles: Competitive Dynamics and Policy Dilemmas in a Multisectoral Image-Producing Complex", Annals of the Association of American Geographers, 86(2): 306-323.

Scott, A.J. (1997) “The Cultural Economy of Cities", International Journal of Urban and Regional Research, 21(2): 323-339.

Scott, A.J. (1998a) "From Silicon Valley to Hollywood: Growth and Development of the Multimedia Industry in California”, in Braczyk H-J., Cooke P. \& Heidenreich M. (eds.), Regional Innovation Systems, London: UCL Press, pp. 136-162.

Scott, A.J. (1998b) Regions and the World Economy: The Coming Shape of Global Production, Competition and Political Order, Oxford: Oxford University Press.

Scott, A. (1999) "The Cultural Economy: Geography and the Creative Field", Media, Culture and Society, 21(6): 807-817.

Scott, A.J. (2000a) The Cultural Economy of Cities, London: Sage Publications. 
Scott, A.J. (2000b) "The Cultural Economy of Paris", International Journal of Urban and Regional Research, 24(3): 567-582.

Scott, A.J. (2001) "Capitalism, Cities, and the Production of Symbolic Forms", Transactions of the Institute of British Geographers NS 26, pp. 11-23.

Shapiro, J. M, (2005) "Smart cities: quality of life, productivity and the growth effects of human capital”, NBER Working paper 11615, National Bureau of Economic Research, September.

Starkey, K., C. Barnatt \& S. Tempest (2000) "Beyond Networks and Hierarchies: Latent Organizations in the U.K. Television Industry", Organization Science, 11(3): 299305.

Storper, M. (1997) "Regional Economies as Relational Assets” in Lee, R. \& J. Willis (eds.), Geographies of Economies, London: Arnold, pp. 248-258.

Storper, M. \& S. Christopherson (1987) "Flexible Specialisation and Regional Industrial Agglomerations: The Case of the US Motion-Picture Industry", Annals of the Association of American Geographers, 77(1): 260-282.

Storper, M. \& B. Harrison (1991) "Flexibility, Hierarchy and Regional Development: The Changing Structure of Industrial Production Systems and their Forms of Governance in the 1990s", Research Policy, 20(5): 407-422.

Storper, M. \& A.J. Venables (2004) “Buzz: Face-to-Face Contact and the Urban Economy”, Journal of Economic Geography, 4(4): 351-370.

Sydow, J. \& U. Staber (2002) "The Institutional Embeddedness of Project Networks: the Case of Content Production in German Television”, Regional Studies, 36(3): 215-227.

Thurow, L. (1996) The Future of Capitalism: How Today's Economic Forces Shape Tomorrow's World, New York: William Morrow and Company.

Toffler, A. (1980) The third Wave, New York: Bamtam Books. 
Van den Berg, L., E. Braun \& W. van Winden (2001) “Growth Clusters in European Cities: An Integral Approach", Urban Studies, 38(1): 185-205.

Venables, A.J. (2001) “Geography and International Inequalities: The Impact of New Technologies", paper presented for World Bank Annual Conference of Development Economics, Washington, D.C., May 2001.

Vogel, H. (1990) Entertainment Industry Economics, 3d ed., Cambridge, UK: Cambridge University Press.

Von Streit, A., Montanari, G., Popp, M., Hafner, S., Heinritz, G., Miosga, M. (2010) Policies and strategies for the creative knowledge economy in the region of Munich: how to enhance the city's competitiveness, ACRE report 10.7, Accomodating Creative Knowledge - Competitiveness fof European Metropolitan Regions within the Enlarged Union, University of Amsterdam, Amsterdam.

Waterman, D. (1990) "Diversity and Quality of Information Products in Monopolistically Competitive Markets", Information Economics and Policy, 4(4): 291-303.

Waters, M. (1995) Globalization, London: Routledge.

Wheeler, J.O., Y. Aoyama \& B. Warf (2000) Cities in the Telecommunications Age. The Fracturing of Geography, New York: Routledge.

Wolfe, D.A., C. Davis \& M. Lucas (2005) "Global Networks and Local Linkages: an Introduction", in Wolfe, D.A. \& M. Lucas (eds.), Global Networks and Local Linkages: The paradox of Cluster Development in an Open Economy, Kingston: McGill-Queen‘s University Press: pp. 1-22.

Zukauskeite, E. (2010) "Innovation in cultural industries: the role of university links", Centre for Innovation, Research and Competence in the Learning Economy (CIRCLE), Paper no. 2010/15, Lund University, 24 pages. 
Zukin, S. (1995) The Cultures of Cities, Cambridge, MA: Blackwell. 
Table 1

\begin{tabular}{cccc}
\hline Service rank & City & Media rank & Difference \\
\hline 1 & London & 1 & 0 \\
2 & New York & 2 & 0 \\
3 & Hong Kong & 20 & -17 \\
4 & Paris & 3 & +1 \\
5 & Tokyo & 18 & -13 \\
6 & Singapore & 12 & -6 \\
\hline 7 & Chicago & 24 & -17 \\
8 & Milan & 5 & +3 \\
9 & Lo Angeles & 4 & +5 \\
10 & Toronto & 8 & +2 \\
11 & Madrid & 6 & +5 \\
12 & Amsterdam & 7 & +5 \\
13 & Sidney & 11 & +2 \\
14 & Frankfurt & 27 & -13 \\
15 & Brussels & 19 & -4 \\
16 & Sao Paulo & 25 & -9 \\
17 & San Fransisco & 33 & -16 \\
18 & Mexico City & 32 & -14 \\
19 & Zurich & 14 & +5 \\
20 & Taipei & 41 & -21 \\
\hline
\end{tabular}

Table 1: Top 20 service business cities rank by media connectivity. Source: Krätke \& Taylor, 2004: 464.

Table 2: 


\begin{tabular}{lccc} 
Region name & CCI Rank & CCI Employment & CCI LQ \\
\hline Île de France (Paris) FR & 1 & 279361 & 1,72 \\
\hline Inner London, UK & 2 & 239983 & 2,77 \\
Lombardia,(Milan) IT & 3 & 175580 & 1,31 \\
Madrid, ES & 4 & 164269 & 1,65 \\
Cataluña (Barcelona) ES & 5 & 139278 & 1,26 \\
Lazio (Rome) IT & 6 & 113531 & 1,97 \\
Danmark & 7 & 98866 & 1,17 \\
Oberbayern (München) DE & 8 & 94178 & 1,57 \\
Attiki (Athens) GR & 9 & 88195 & 1,47 \\
Outer London, UK & 10 & 86884 & 1,43 \\
Kozep-Magyarorszag (Budapest) HU & 11 & 79281 & 1,44 \\
Zuid-Holland NL & 12 & 78183 & 1,90 \\
Berks, Bucks and Oxon (Oxford) UK & 13 & 76097 & 1,80 \\
Noord-Holland (Amsterdam) NL & 14 & 74685 & 0,68 \\
Andalucia (Sevilla) ES & 15 & 70914 & 1,37 \\
Köln DE & 16 & 68825 & 2,87 \\
Stockholm, SE & 17 & 68212 & 1,35 \\
Lisboa, PT & 18 & 67929 & 1,70 \\
Berlin, DE & 19 & 66051 & 0,94 \\
Veneto IT & 20 & 61285 & 0,68 \\
Niedersachsen DE & 21 & 59486 & 1,15 \\
Darmstadt (Hanover) DE & 22 & 58965 & 1,09 \\
Piemonte IT & 23 & 58068 & 0,95 \\
Emilia-Romagna IT & 24 & 58029 & 1,40 \\
\hline Surrey E and W Sussex UK & 25 & 57837 & \\
\hline
\end{tabular}

Table 2: Europe top 25 regions for creative and cultural industry $(\mathrm{CCI})$ and their employment ${ }^{17}$. Source: Dominic Power (2011:9).

Figure 1:

\footnotetext{
${ }^{17} \mathrm{LQ} 1$ is an indicator of CCI employment relative to the total employment of the region. If $\mathrm{LQ}>1$ it indicates an over-employment of CCI in the region.
} 


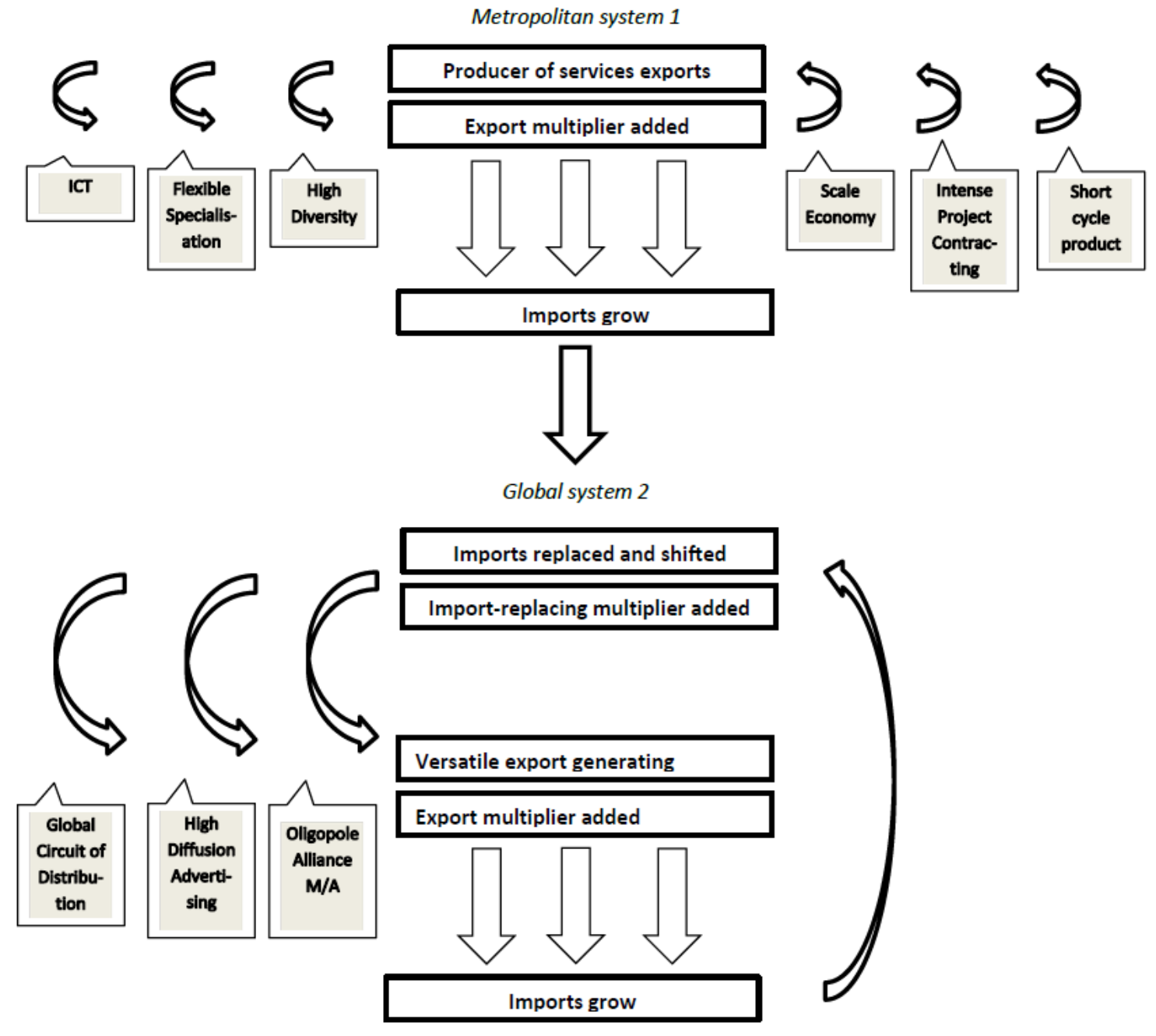

Figure 1: The Jacobian model of agglomeration growth for media cluster. Source: Jacobs, 1969: 260. 